\title{
Pola Pertumbuhan Siput Gonggong Strombus turturella, Röding, 1798 (Gastropoda: Strombidae) di Pulau Bangka, Bangka Belitung
}

\author{
Okto Supratman ${ }^{*}$, Indah Auliana', Mualimah Hudatwi², dan Eva Utami² \\ IJurusan Manajemen Sumberdaya Perairan, Fakultas Pertanian Perikanan dan Biologi, \\ Universitas Bangka Belitung \\ 2Jurusan IImu Kelautan, Fakultas Pertanian, Perikanan dan Biologi, Universitas Bangka Belitung \\ Kampus Terpadu - Universitas Bangka Belitung, Kab. Bangka, Kepulauan Bangka Belitung, 33172 \\ Email : oktosupratman@gmail.com
}

\section{Abstract \\ Growth Pattern of Strombus Turturella, Röding, 1798 (Gastropoda: Strombidae) in Bangka Island Bangka Belitung}

Strombus turturella on Bangka Island is under pressure and threatens the effects of anthropogenic activity. This condition is necessary to carry out various efforts to manage the dog conch on an ongoing basis. Based on these problems, it is necessary to conduct research related to various parameters of the growth of the dog conch on Bangka Island. The purpose of the study was to determine the growth parameters of the dog conch which included growth patterns, estimation of growth model von bertalanffy and length-weight relationship. The research was carried out in several stages, namely: 1) Sampling in the field conducted in Teluk Kelabat waters, Ketawai Island and Anak Air Island, 2) Measurement of shell length and weight, and 3) Analysis of growth parameters using the FiSAT II application, then estimated von Bertalanffy's growth. The results of the frequency distribution of the size of the gonggong snail class in Teluk Kelabat were 47.85- $66.35 \mathrm{~mm}$, on Ketawai Island 44.10-77.45 mm, while those on Anak Air Island were 44.10-62.65 $\mathrm{mm}$. The results of Von Bertalanffy's growth model in the first year or age of one year growth accelerated with the length of the shell in Teluk Kelabat $(44.46 \mathrm{~mm})$, Ketawai Island $(46.63 \mathrm{~mm})$ and Pulau Anak Air (32, $80 \mathrm{~mm})$. Then in the following year the growth slowed down to asymptotic length with around 11 years of age in T. Kelabat, 14 years in P. Ketawai and 15 years in P. Anak Air. The relationship between the length and weight of the dog conch in three locations on Bangka Island with a value of $b<3$ so that a negative allometric growth pattern can be determined. The negative allometric growth pattern shows an increase in the length of the snail bark faster than the weight gain.

Keywords: Bangka Island; dog conch; growth; length- weight relationship

\begin{abstract}
Abstrak
Siput gonggong (Strombus turturella) di Pulau Bangka mengalami tekanan dan ancaman dampak dari aktivitas antropogenik. Kondisi ini maka perlu dilakukan berbagai upaya pengelolaan siput gonggong secara berkelanjutan. Berdasarkan permasalahan tersebut maka perlu dilakukan penelitian berkaitan berbagai parameter pertumbuhan siput siput gonggong di Pulau Bangka. Tujuan penelitian yaitu menentukan beberapa parameter pertumbuhan siput gonggong yang meliputi distribusi kelas ukuran, pendugaan model pertumbuhan von bertalanffy dan hubungan panjang berat. Penelitian dilakukan beberapa tahapan yaitu 1) Pengambilan sampel di lapangan yang dilakukan di Perairan Teluk Kelabat, Pulau Ketawai dan Pulau Anak Air, 2) Pengukuran panjang cangkang dan berat, dan 3) Analisis parameter pertumbuhan dengan menggunakan aplikasi FiSAT II, selanjutnya dihitung pendugaan pertumbuhan von Bertalanffy. Hasil distribusi frekuensi kelas ukuran siput gonggong di Teluk Kelabat yaitu $47.85 \mathrm{~mm}$ s.d $66.35 \mathrm{~mm}$, di Pulau Ketawai $44.10 \mathrm{~mm}$ s.d $77.45 \mathrm{~mm}$, sedangkan di Pulau Anak Air yaitu $44.10 \mathrm{~mm}$ s.d $62.65 \mathrm{~mm}$. Hasil model pertumbuhan Von Bertalanffy pada tahun pertama atau umur satu tahun pertumbuhan
\end{abstract}


mengalami percepatan dengan panjang cangkang di Teluk Kelabat $(44,46 \mathrm{~mm})$, Pulau Ketawai $(46,63)$ dan Pulau Anak Air $(32,80) \mathrm{mm}$. Kemudian pada tahun selanjutnya pertumbuhan semakin melambat sampai mecapai panjang asimtotik dengan umur sekitar 11 tahun di T. Kelabat, 14 tahun di P. Ketawai dan 15 tahun di P. Anak Air. Hubungan panjang dan berat siput gonggong di tiga lokasi di Pulau Bangka dengan nilai $b<3$ sehingga dapat ditentukan pola pertumbuhan alometrik negatif. Pola pertumbuhan alometrik negatif menunjukan pertambahan panjang siput gonggong lebih cepat dibandingkan dengan pertambahan berat.

Kata kunci : Hubungan Panjang Berat; Pertumbuhan; Pulau Bangka; Siput Gonggong

\section{PENDAHULUAN}

Siput gonggong (Strombus turturella) adalah biota laut yang termasuk filum moluska dari kelas gastropoda yang memiliki nilai ekonomis dengan kandungan gizi yang tinggi sehingga sering dimanfaatkan masyarakat (Rasyid dan Dody, 2018; Viruly et al, 2019). Siput gonggong di Indonesia telah dilaporkan ditemukan di daerah Kepulauan Riau dan Kepulauan Bangka Belitung (Dody, 2011; Muzahar and Hakim, 2019). Distribusi siput gonggong di Kepulauan Bangka Belitung meliputi Teluk Kelabat, Kab. Bangka Barat, Tanjung Rusa Kab. Belitung, Pesisir Tukak, Pulau Anak Air Kab. Bangka Selatan dan Pulau Ketawai Kab. Bangka Tengah (Dody dan Marasabessy 2007; Supratman \& Syamsudin, 2018).

Keberadaan siput gonggong di Pulau Bangka mengalami tekanan dan ancaman dampak dari aktifitas antropogenik seperti penambangan timah di laut, pencemaran, penangkapan menggunakan trawl dan eksploitasi secara berlebihan (Dody dan Marasabessy 2007; Dody 2011). Kegiatan tersebut bukan hanya berdampak pada ukuran populasi di alam akan tetapi berdampak pada ukuran cangkang atau pertumbuhan siput gonggong. Hal ini telah dilaporkan sebelumnya bahwa ada perbedaan ukuran cangkang siput gonggong dampak dari aktivitas pertambangan timah di Pulau Bangka (Dody dan Marasabessy 2007). Akan tetapi penelitian yang berkaitan dengan pertumbuhan siput gonggong belum banyak di Lakukan, sedangkan data parameter pertumbuhan merupakan bagian penting dalam upaya pengelolaan siput gonggong di Pulau Bangka.

Parameter pertumbuhan dapat ditentukan dengan beberapa persamaan dan menggunakan aplikasi di bidang perikanan salah satunya yaitu FiSAT II (FAOICLRAM Stock Assessment Tools) (Gyanilo and Pauly, 1997). Penggunaan aplikasi FiSAT ॥ sudah dilakukan beberapa peneliti sebelumnya untuk menduga beberapa parameter pertumbuhan pada genus strombus (Cob et al, 2009; Cárdenas and Aranda, 2014). Hal ini dilakukan dikarenakan aplikasi FiSAT II mudah digunakan dan hanya memerlukan data frekuensi kelas ukuran untuk menentukan beberapa parameter pertumbuhan (Gyanilo and Pauly, 1997; Cob et al, 2009). Berdasarkan parameter pertumbuhan dapat menentukan model pertumbuhan, selain itu dapat menduga keterkaitan kondisi habitat terhadap pertumbuhan ukuran siput gonggong di Pulau Bangka. Hasil ini sehingga dapat dijadikan acuan untuk pemanfaatan dan pengelolaan siput gonggong secara berkelanjutan di Pulau Bangka.

\section{MATERI DAN METODE}

Pengambilan sampel dibagi menjadi tiga lokasi yaitu di Perairan Teluk Kelabat Kabupaten Bangka, Pulau Ketawai Kabupaten Bangka Tengah dan Pulau Anak Air Kabupaten Bangka Selatan, Provinsi Bangka Belitung (Gambar 1). Penentuan titik lokasi pengambilan sampel dilakukan berdasarkan keberadaan siput gonggong dan perbedaan karakteristik habitat di setiap lokasi penelitian (Tabel 1). Pengambilan sampel dilakukan ketika kondisi perairan surut di siang hari agar mempermudah kegiatan yang dilakukan. Sampel gonggong diambil secara acak dengan koleksi langsung menggunakan tangan (hand collecting). Kemudian sampel tersebut dimasukan kedalam plastik sampel untuk diukur panjang cangkang dan berat yang dilakukan di laboratorium. Jumlah sampel siput gonggong yang diambil \pm 100 individu di setiap lokasi. 


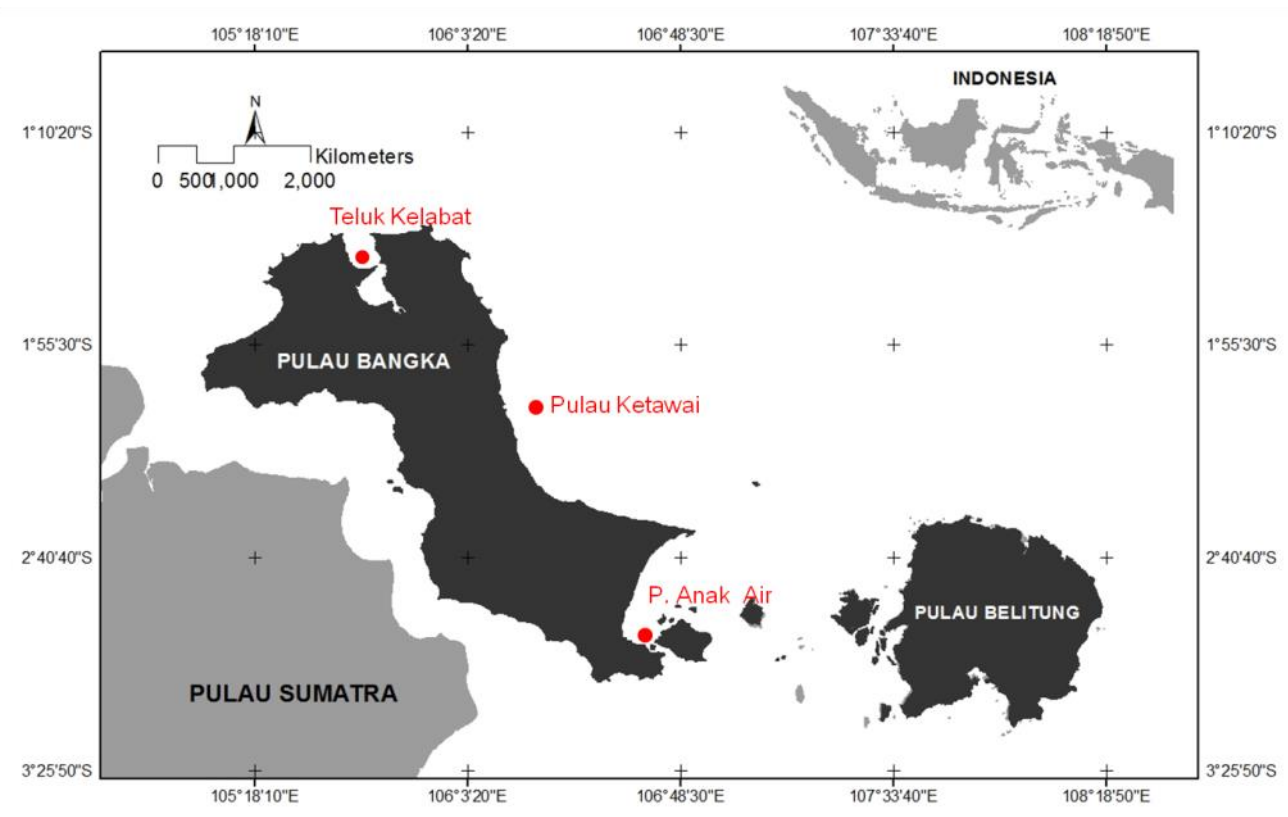

Gambar 1. Peta Lokasi Penelitian

Tabel 1 Karakteristik lokasi penelitian di Pulau Bangka

\begin{tabular}{|c|c|c|c|}
\hline No & Lokasi & Titik Koordinat & Karakteristik Lokasi \\
\hline 1 & Teluk Kelabat & $\begin{array}{l}02^{0} 59^{\prime} 09.5^{\prime \prime} \mathrm{S} \\
106^{0} 38^{\prime} 50.5^{\prime \prime} \mathrm{E}\end{array}$ & $\begin{array}{l}\text { Aktivitas nelayan, substrat berpasir dan ditemukan } 2 \\
\text { jenis lamun }\end{array}$ \\
\hline 2 & Pulau Ketawai & $\begin{array}{l}2^{\circ} 16^{\prime} 12.18^{\prime \prime S} \\
106^{\circ} 19^{\prime} 34.40^{\prime \prime} \mathrm{E}\end{array}$ & $\begin{array}{l}\text { Aktivitas pariwisata, substrat berpasir dan ditemukan } \\
7 \text { jenis lamun }\end{array}$ \\
\hline 3 & Pulau Anak Air & $\begin{array}{l}2^{\circ} 57^{\prime} 42.42^{\prime \prime S} \\
106^{\circ} 39^{\prime} 51.01^{\prime \prime} \mathrm{E}\end{array}$ & $\begin{array}{l}\text { Daerah tangkapan nelayan, Perairan relatif dalam, } \\
\text { substrat pasir berlempung dan tidak ditemukan } \\
\text { lamun (seagrass) }\end{array}$ \\
\hline
\end{tabular}

Sampel siput gonggong yang ditemukan dari lapangan diukur panjang cangkang dan Berat. Panjang cangkang siput gonggong diukur mulai dari bagian apex pada posterior sampai dengan bagian paling bawah cangkang pada anterior (Chiu et al, 2002; Cob et al, 2008a). Pengukuran panjang cangkang menggunakan kapiler dengan ketelitian 0,02 mm. Pengukuran berat dilakukan dengan menimbang siput gonggong menggunakan timbangan Ohaus dengan ketelitian 0,01 gram. Panjang cangkang dan berat siput digunakan untuk menentukan beberapa parameter pertumbuhan dan hubungan panjang berat siput gonggong.

Distribusi frekuensi kelas ukuran ditentukan berdasarkan ukuran populasi hasil dari lapangan dan ukuran panjang cangkang hasil dari pengukuran di laboratorium. Penentuan distribusi kelas ukuran pertama- tama menentukan kisaran kelas ukuran, jumlah kelas ukuran dan panjang kelas dengan menggunakan rumus secara berurutan (Walpole, 1995).

Hasil distribusi frekuensi kelas ukuran kemudian dapat menentukan pola pertumbuhan dengan menggunakan persamaan model von Bertalanffy (Sparre dan Venema, 1998; Gayanilo dan Pauly, 1997). Sebelum menghitung persamaan von Bertalanffy perlu diketahui nilai panjang asimtotik $\left(L_{\infty}\right), K$ dan to terlebih dahulu. Nilai $L_{\infty}$ dan $K$ ditentukan dengan menggunakan ELEFAN I (Electronic length frequency analysis) menggunakan program komputer FITSAT II (FAO-ICLRAM Stock Assessment Tools) (Gayanilo dan Pauly, 1997). Penentuan nilai $\dagger$ dihitung berdasarkan nilai $L_{\infty}$ dan $K$ dengan menggunakan persamaan Pauly (1979). Hubungan panjang berat dihitung menggunakan persamaan (Effendie, 2002). Hasil tersebut apabila nilai $b=3$ maka 
hubungan panjang dengan berat adalah isometrik, sedangkan jika nilai $b \neq 3$ maka hubungan panjang dengan berat adalah allometrik. Isometrik berarti pertambahan panjang seimbang dengan pertambahan bobot. Allometrik positif, jika $b \geq 3$ (pertambahan bobot lebih cepat dari pada pertambahan panjang) dan allometrik negatif, jika $b<3$ (pertambahan panjang lebih cepat dari pada pertambahan bobot) (Effendie, 2002).

\section{HASIL DAN PEMBAHASAN}

Berdasarkan penelitian di tiga lokasi dengan jumlah sampel 300 individu siput gonggong diketahui panjang cangkang berkisar 42,30-76,30 mm. Hasil dari pengukuran panjang cangkang diketahui panjang kelas ukuran yaitu $3.70 \mathrm{~mm}$ sehingga dapat ditentukan 10 frekuensi kelas ukuran. Kisaran kelas siput gonggong di Teluk Kelabat yaitu $47.85 \mathrm{~mm}$ s.d $66.35 \mathrm{~mm}$, di Pulau Ketawai $44.10 \mathrm{~mm}$ s.d $77.45 \mathrm{~mm}$, sedangkan di Pulau Anak Air yaitu $44.10 \mathrm{~mm}$ s.d 62.65 mm (Gambar 1)
Distribusi frekuensi ukuran siput gonggong di Pulau Bangka ada perbedaan atau variasi di setiap lokasi. Kelas ukuran di Pulau Ketawai dan Teluk kelabat paling tinggi pada kelas $55,25 \mathrm{~mm}$, sedangkan di Pulau Anak Air kelas ukuran tertinggi yaitu 51,55 $\mathrm{mm}$. Hasil ini menunjukkan Frekuensi kelas ukuran di pulau anak air berbeda dengan lokasi lainnya di Pulau Bangka. Hasil penelitian Supratman (2015) ada perbedaan distribusi frekuensi kelas ukuran siput gonggong pada beberapa lokasi dipengaruhi oleh perbedaan waktu rekruitmen dan kondisi habitat. Sedangkan pada penelitian ini perbedaan waktu rekruitmen tidak terlalu berpengaruh terhadap distribusi ukuran dikarenakan sampling dilakukan pada waktu hampir bersamaan di setiap lokasi yaitu pada bulan Mei s.d Juni 2019. Selain itu individu-individu yang ditemukan di setiap lokasi menunjukkan pola umur yang hampir sama yaitu individu dewasa, hal ini dicirikan dengan ketebalan bibir cangkang dengan ukurannya relatif sama pada setiap individu yang ditemukan di Pulau Anak Air maupun di lokasi lainnya.

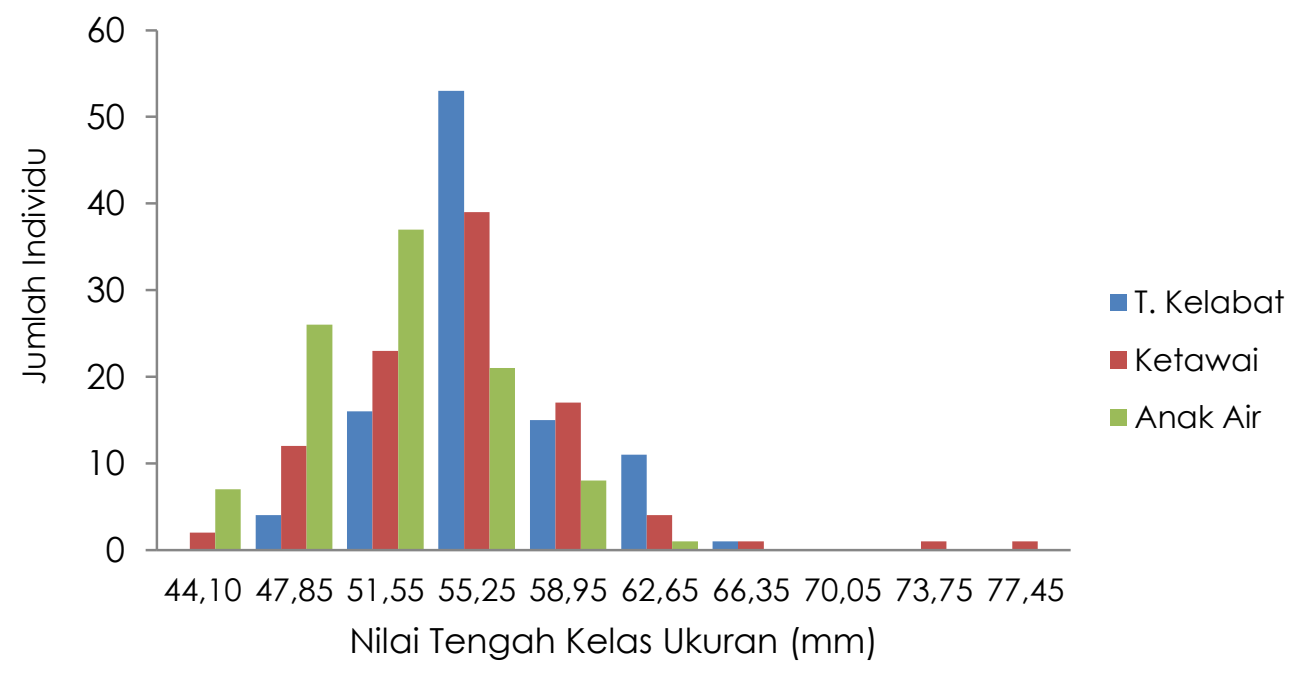

Gambar 1. Distribusi Frekuensi Kelas Ukuran di perairan Teluk Kelabat, Pulau Ketawai, dan Pulau Anak Air

Table 2. Parameter Pertumbuhan ukuran siput gonggong di Pulau Bangka

\begin{tabular}{lccc}
\hline \multicolumn{1}{c}{ Lokasi } & $L_{\infty}(\mathrm{mm})$ & K (per tahun) & to (Tahun) \\
\hline Teluk Kelabat & 69.67 & 0.89 & -0.142 \\
Pulau Ketawai & 81.27 & 0.73 & -0.167 \\
Pulau Anak Air & 65.73 & 0.56 & -0.233 \\
\hline
\end{tabular}


Apabila dibandingkan dengan penelitian Supratman (2015) ada perbedaan kelompok umur di setiap lokasi yaitu kelompok umur muda, umur dewasa dan tua. Secara eksternal untuk membedakan individu dewasa dan muda pada genus strombus termasuk siput gonggong dapat ditentukan dari ketebalan bibir cangkang, diameter operkulum dan panjang cangkang (Cob et al, 2008b, Stoner et al., 2012; Muler dan Stoner, 2013; Supratman, 2015).

Hasil penelitian menunjukkan faktor yang paling menentukan perbedaan kelas ukuran antara pulau Anak air dengan Pulau Ketawai dan Teluk Kelabat yaitu Kondisi Habitat. Berdasarkan karakteristik lokasi Pulau Anak Air berbeda dengan Pulau Ketawai dan Teluk Kelabat. Pulau Anak air dengan kondisi perairan yang dalam, substrat pasir berlumpur dan tidak ditemukan tumbuhan lamun, sedangkan di Pulau Ketawai dan Teluk Kelabat kondisi substrat berpasir dan ditemukan tumbuhan lamun (Tabel 1). Siput gonggong merupakan hewan detritivore yang mengkonsumsi bahan-bahan organik yang telah mati termasuk dari tumbuhan lamun (Cob et al, 2014; Supratman dan Syamsudin, 2016). Keberadaan lamun dapat meningkatkan bahan organik yang menjadi sumber nutrisi bagi siput gonggong, sehingga dapat meningkatkan pertumbuhan pada hewan tersebut. Kondisi ini yang menyebabkan adanya perbedaan distribusi ukuran siput gonggong di Pulau Anak Air dengan Lokasi lainnya.

\section{Parameter Pertumbuhan}

Hasil perhitungan parameter pertumbuhan menggunakan program FiSAT II di dapat nilai panjang asimtotik $\left(L_{\infty}\right)$, koefisien pertumbuhan (K), kemudian dianalisis lanjutan dapat menentukan nilai to siput gonggong di Pulau Bangka. Panjang asimtotik $\left(L_{\infty}\right)$ siput gonggong di beberapa lokasi di Pulau Bangka, ada perbedaan dimana di mana nilai $L_{\infty}$ paling tinggi ditemukan di Pulau Ketawai Bangka Tengah $\left(L_{\infty}=81,27\right)$, sedangkan paling rendah di Pulau Anak Air Bangka Selatan $\left(L_{\infty}=65,73\right)$ (Tabel 2). Panjang asimtotik merupakan panjang cangkang maksimal yang mampu dicapai individu siput gonggong atau panjang cangkang pada individu yang sangat tua (Sparre dan Venema, 1998;
Supratman, 2015). Nilai panjang asimtotik siput gonggong (S. turturella) di tiga lokasi penelitian ini lebih rendah bila dibandingkan dengan penelitian lainnya di Pesisir Desa Tukak dengan nilai asimtotik yaitu 83.94 (Supratman, 2015). Berdasarkan data parameter pertumbuhan yang meliputi nilai panjang asimtotik $\left(L_{\infty}\right), \quad$ koefisien pertumbuhan (K) dan nilai to dapat ditentukan model pertumbuhan Von Bertalanffy (Gayanilo dan Pauly, 1997). Hasil model pertumbuhan Von Bertalanffy pada tahun pertama atau umur satu tahun pertumbuhan mengalami percepatan dengan panjang cangkang di Teluk Kelabat $(44,46 \mathrm{~mm})$, Pulau Ketawai $(46,63)$ dan Pulau Anak Air $(32,80) \mathrm{mm}$. Kemudian pada tahun selanjutnya pertumbuhan semakin melambat sampai mecapai panjang asimtotik dengan umur sekitar 11 tahun di T. Kelabat, 14 tahun di P. Ketawai dan 15 tahun di P. Anak Air (Tabel 3 dan Gambar 2).

Hasil penelitian ini menunjukkan pola pertumbuhan siput gonggong di P. Anak Air berbeda dengan lokasi lainnya dan pertumbuhannya sedikit melambat. Perbedaan pertumbuhan siput gonggong di beberapa lokasi Pulau Bangka di duga dipengaruhi oleh perbedaan karakteristik habitat di setiap lokasi. Hal ini dikarenakan karakteristik habitat di P. Anak air berbeda dengan di T. Kelabat dan P. Ketawai.

\section{Hubungan Panjang dan Berat}

Hasil analisis hubungan panjang dan berat siput gonggong (Strombus turturella) pada tiga lokasi diperoleh model pendugaan hubungan panjang berat. Model pendugaan Hubungan panjang berat di pada Teluk Kelabat adalah $\mathrm{W}=0,0045 \mathrm{~L} 2,0819$ dengan nilai koefisien determinan $\left(R^{2}\right)=0,376$, dan nilai $b=$ 2,081 . Hasil pendugaan hubungan panjang berat di Pulau Ketawai dengan nilai $\mathrm{W}=$ $0,0047 L^{2,0744}$, koefisien determinan $\left(R^{2}\right)$ sebesar 0,4263 , dan nilai $b=2,074$. Sedangkan untuk hubungan panjang berat di Pulau Anak air dengan model pendugaan hubungan panjang berat yaitu $\mathrm{W}=0,0008$ L2,5237 dengan nilai koefisien determinan $\left(R^{2}\right)$ sebesar 0,6524 , dan nilai b yaitu 2,524 (Gambar 3; Tabel 4).

Hasil analisis hubungan panjang dan berat siput gonggong ( $S$. turturella) di tiga lokasi di Pulau Bangka dengan nilai $b<3$ sehingga dapat ditentukan pola 
pertumbuhan yaitu alometrik negatif. Hasil penelitian ini bila dibandingkan dengan penelitian lainnya di perairan Batam, Kepulauan Riau dengan pola pertumbuhan siput gonggong sama yaitu alometrik negatif (Ramses et al, 2019). Pola pertumbuhan alometrik negatif menunjukkan pertambahan panjang siput gonggong lebih cepat dibandingkan dengan pertambahan berat (Effendie, 2002; Ramses et al, 2019). Hal ini sesuai dengan perhitungan model pertumbuhan von Bertalanffy siput gonggong mengalami percepatan pertumbuhan panjang cangkang dari usia 0 s.d 1 tahun, kemudian terjadi pertambahan panjang cangkang sampai umur lebih dari 11 tahun.

Tabel 3. Model pertumbuhan Von Bertalanffy Siput Gonggong di Pulau Bangka

\begin{tabular}{cccc}
\hline \multirow{2}{*}{ Umur (tahun) } & \multicolumn{3}{c}{ Panjang cangkang $\left(\mathrm{L}_{+}\right)(\mathrm{mm})$} \\
\cline { 2 - 4 } & T. Kelabat & P. Ketawai & P. Anak Air \\
\hline 0 & 0 & 0 & 0 \\
1 & 44.46 & 46.63 & 32.80 \\
3 & 59.32 & 64.57 & 46.92 \\
4 & 65.42 & 73.22 & 54.98 \\
5 & 67.92 & 77.39 & 59.59 \\
6 & 68.95 & 79.40 & 62.22 \\
7 & 69.38 & 80.37 & 63.73 \\
8 & 69.55 & 80.84 & 64.59 \\
9 & 69.62 & 81.06 & 65.08 \\
10 & 69.65 & 81.17 & 65.36 \\
11 & 69.66 & 81.22 & 65.52 \\
12 & 69.67 & 81.25 & 65.61 \\
13 & 69.67 & 81.26 & 65.66 \\
14 & 69.67 & 81.26 & 65.69 \\
15 & 69.67 & 81.27 & 65.71 \\
\hline
\end{tabular}

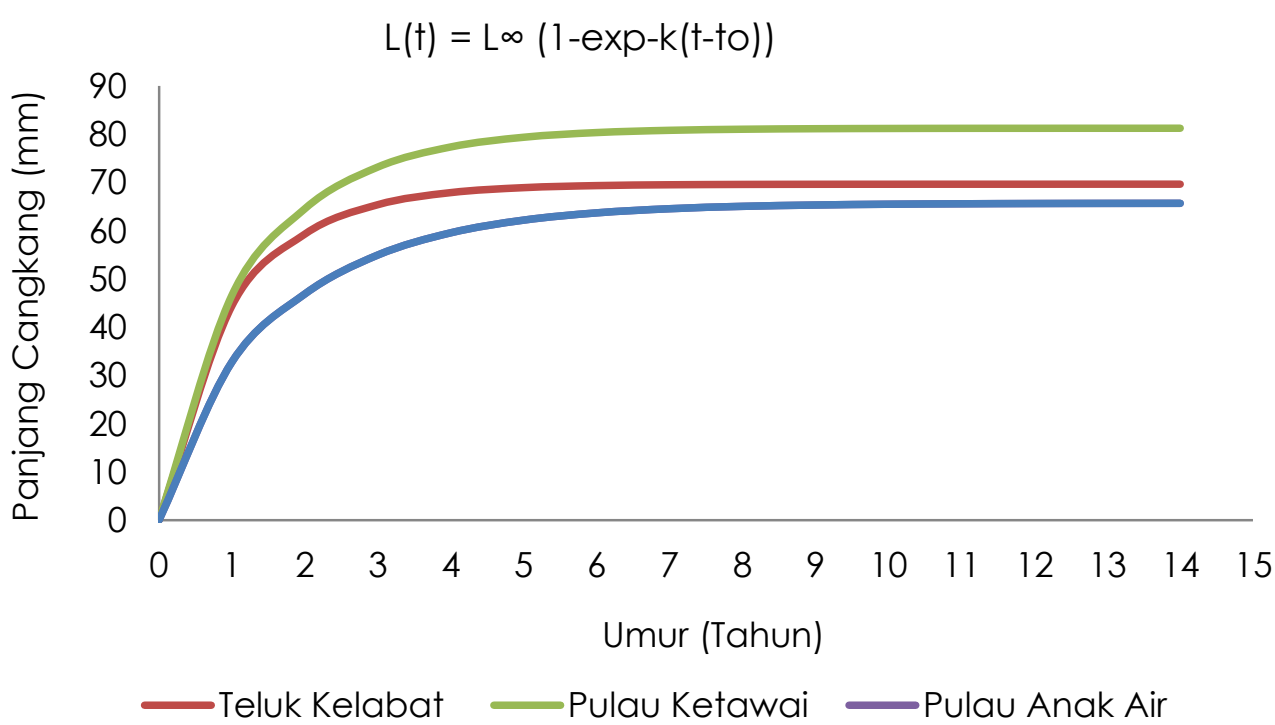

Gambar 2. Model pertumbuhan von Bertalanffy siput gonggong Pulau Bangka 
Tabel 4. Hasil perhitungan hubungan panjang berat siput gonggong di Pulau Bangka

\begin{tabular}{lccccc}
\hline \multicolumn{1}{c}{ Lokasi } & $\mathrm{N}$ (individu) & $\mathrm{a}$ & $\mathrm{b}$ & $\mathrm{R}^{2}$ & Pola Pertumbuhan \\
\hline Teluk Kelabat & 100 & 2,54 & 2,26 & 0,43 & Alometrik Negatif \\
Pulau Ketawai & 100 & 2,50 & 2,24 & 0,48 & Alometrik Negatif \\
Pulau Anak Air & 100 & 3,06 & 2,58 & 0,71 & Alometrik Negatif \\
\hline
\end{tabular}

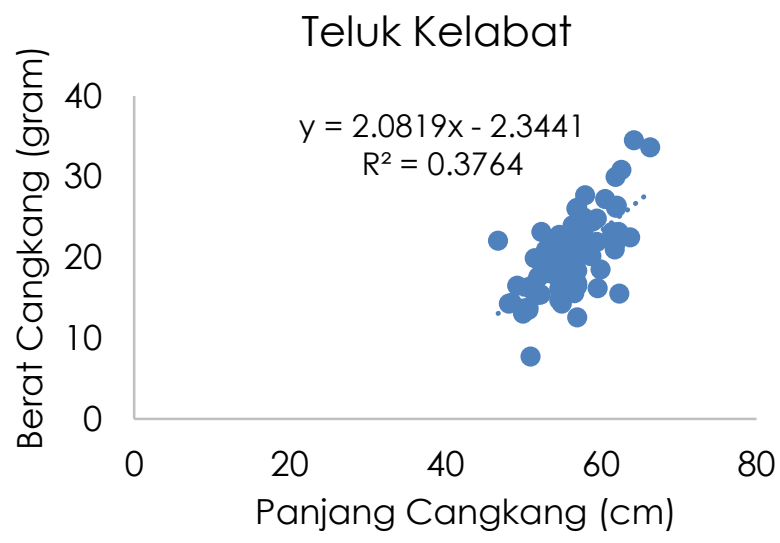

Pulau Ketawai
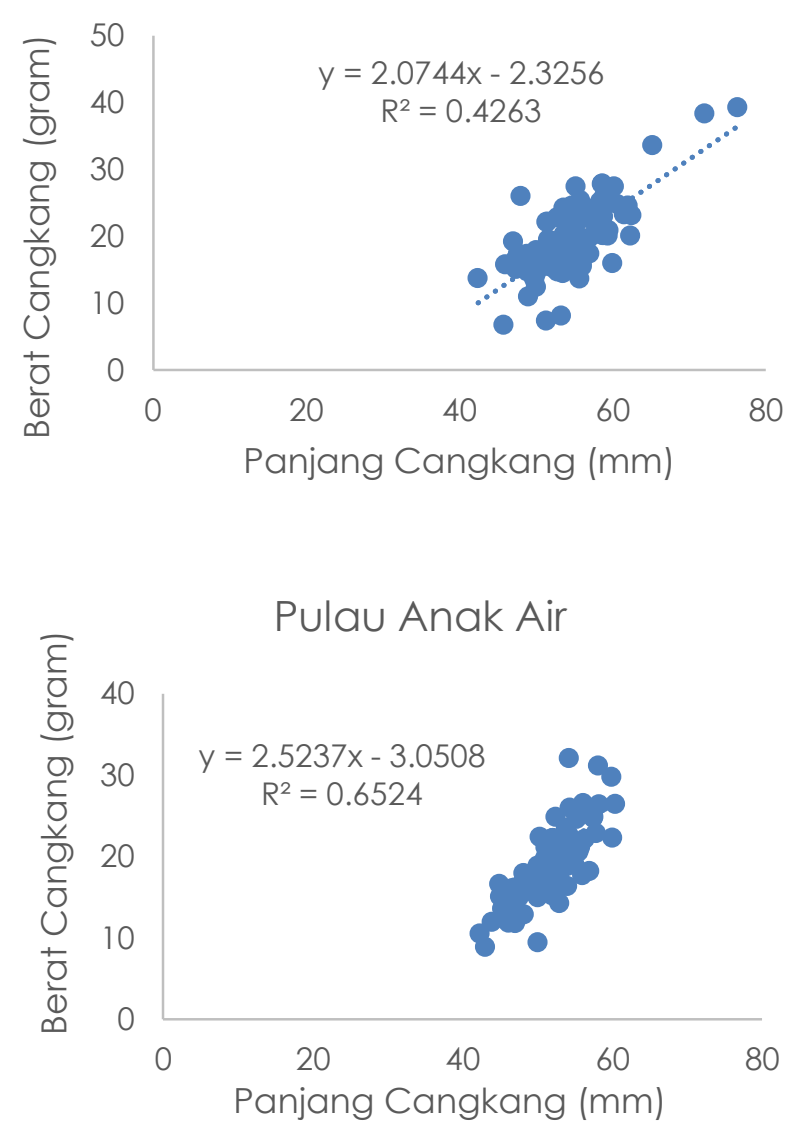

Gambar 3. Hubungan panjang dan berat Siput gonggong di Pulau Bangka 


\section{KESIMPULAN}

Distribusi frekuensi kelas ukuran siput gonggong (S. turturella) ada perbedaan antara Pulau Anak Air dengan Lokasi lainnya di Pulau Bangka. Perbedaan tersebut disebabkan oleh perbedaan karakteristik habitat pada lokasi penelitian. Model pertumbuhan Von Bertalanffy pada tahun pertama atau umur satu tahun pertumbuhan mengalami percepatan dengan panjang cangkang di Teluk Kelabat (44,46 mm), Pulau Ketawai $(46,63)$ dan Pulau Anak Air $(32,80)$ $\mathrm{mm}$. Kemudian pada tahun selanjutnya pertumbuhan semakin melambat sampai mencapai panjang asimtotik dengan umur sekitar 11 tahun di T. Kelabat, 14 tahun di P. Ketawai dan 15 tahun di P. Anak Air. Pola pertumbuhan siput gonggong di Pulau Bangka yaitu alometrik negatif menunjukkan pertambahan panjang lebih cepat dibandingkan dengan pertambahan berat.

\section{UCAPAN TERIMAKASIH}

Penulis ucapkan terimakasih kepada KEMENRISTEK-DIKTI yang telah menyediakan dana melalui Penelitian Dosen Pemula (PDP) tahun 2019 dengan nomor kontrak 187.U/UN.50.3.1/PP/2019

\section{DAFTAR PUSTAKA}

Cárdenas, B.E., \& Aranda, A.D. 2014. Growth parameters and density variation of a queen conch, Strombus gigas (Neotaenioglossa: Strombidae), population from Xel-Há park, a marine protected area. Revista de Biol. Tropic. 62(1):59-72.

Chiu, Y.W., Chen, H.C., Lee, S.C., \& Chen, C.A. 2002. Morphometric Analysis of Shell and Operculum Variations in the Viviparid Snail, Cipangopaludina chinensis (Mollusca: Gastropoda), in Taiwan. Zoolog. Stud., 41 (3):321-331.

Cob, Z.C., Arshad, A., Idris, M.H., Bujang, J.S., \& Ghaffar, M.A. 2008a. Sexual polymorphism in a population of Strombus canarium Linnaeus, 1758 (Mollusca: Gastropoda) at Merambong Shoal, Malaysia. Zoolog. Stud., 47(3):318325.
Cob, C.Z., Arshad, A., Bujang, J.S., and Ghaffar, M.A. (2008b) : Sexual Maturity and Sex Determination in Strombus canarium Linnaeus, 1758 (Gastropoda: Strombidae). J. Biolog. Sci., 8(3):1-6. doi: 10.3923/jbs.2008.616.621

Cob, Z.C., Arshad, A., Bujang, J.S., \& Ghaffar, M. 2009. Age Growth Mortality and Population Structure Strombus canarium Male and Female. J. App. Sci., 18(9):3287-3297. doi: 10.3923/jas.2009.32 87.3297

Cob, Z.C., Arshad, A., Bujang, J.S., NurulHusna W.H.W., \& Ghafar MA. 2014. Feeding Behaviour and Stomach Content Analysis of Laevistrombus canarium (Linnaeus, 1758) from the Merambong Shoal, Johor, Malaysia. Malayan Nat. J., 66(1-2):184-197.

Dody, S. 2011 . Pola Sebaran, Kondisi Habitat dan Pemanfatan Siput Gonggong (Strombus turturella) di Kepulauan Bangka Belitung. Oseano. Limnol. Ind., $37(2): 339-353$.

Dody, S., \& Marasabessy, M.D. 2007. Habitat dan Sebaran Spasial Siput Gonggong (Strombus turturella), Prosiding Seminar Nasional Moluska dalam Penelitian, Konservasi dan Ekonomi. Semarang, 17 Juli, hal. 100-108.

Effendie, M.I. 2002. Biologi Perikanan, Yayasan Pustaka Nusantara, Yogyakarta

Gayanilo, F.C., \& Pauly, D. 1997. FAO-ICLARM Stock Assessment Tools Reference Manual Stock Assessment Tools Reference Manual, FAO, Rome.

Mueller., K.W. \& Stoner, A.W. 2013. Proxy Measures for Queen Conch (Strombus Gigas Linne, 1758). Age and Maturity: Relationship Between Shell Lip Thickness and Operculum Dimension. J. Shellfish Res. 32(3):739-744. doi: 10.2983/035.032. 0316

Pauly, D. 1979. Theory and Management of Tropical Multispecies Stocks: Review, with Emphasis on the Southeast Asian Demersal Fisheries, ICLARM, Manila.

Ramses, R., Syamsi, F., \& Notowinarto, N .2019. Length-Weight Relationship, Growth Patterns and Sex Ratio of Dog Conch Strombus Canarium Linnaeus, 1758 in the Waters of Kota Batam. OmniAkuatika, 15(1):19-29. doi: 10.20884/1.oa. 2019.15.1.611 
Rasyid, A., \& Dody, S. 2018. Evaluation of the nutritional value and heavy metal content of the dried marine gastropod Laevistrombus turturella. AACL Bioflux, $11(6): 1799-1806$.

Sparre P., \& Venema, S.C. 1998. Introduction Tropical Fish Stock Assessment, FAO, Rome.

Stoner, A.W., Mueller, K.W., Brown-Petersond, N.J., Davise, M.H., \& Bookerf, C.J. 2012. Maturation and Age in Queen Conch (Strombus gigas): Urgent Need for Changes in Harvest Criteria. Fish. Res., 131:76-84. doi: 10.1016/j.fishres. 2012.07 .017

Supratman, O., \& Syamsudin, T. S. 2018. Karakteristik Habitat Siput Gonggong (Strombus turturella) di Ekosistem Padang Lamun. J. Kel. Trop., 21(2):81-90. doi: 10.14710/jkt.v21i2.2969

Supratman, O., \& Syamsudin, T. S. 2016. Behavior and feeding habit of dog conch (Strombus turturella) in South
Bangka Regency, Bangka Belitung islands province. El-Hayah, 6(1):15-21. doi: 10.18860/elha.v6il.4069

Supratman O. 2015. Struktur Populasi, Makanan Alami dan Reproduksi Siput Gonggong (Strombus turturella) di Bangka Selatan, Kepulauan Bangka Belitung [Tesis]. Institut Teknologi Bandung. Bandung.

Viruly, L., Andarwulan, N., Suhartono, M. T., \& Nurilmala, M. 2019. Protein Histon Pada Siput Gonggong Bintan Strombus Sp. Sebagai Kandidat Pangan Fungsional. J. Ilmu Teknol. Kel. Trop., 11(1):89-101. doi: 10.29244/jitkt.v1 1 il.22299

Walpole, R.E. 1995. Pengantar Statistika, Gramedia Pustaka Utama, Jakarta.

Muzahar \& Hakim, A.A. 2018. Spawning and Development of Dog Conch Strombus SP. Larvae in the Laboratory. J. IImu Teknol. Kel. Trop.,10(1):209-216. doi: 10.289 30/jitkt.v4i1.7811 